\title{
The Alcyonaria, Antipatharia, and Madreporaria collected by the "Huxley" from the North Side of the Bay of Biscay in August, 1906.
}

\author{
By \\ Sydney J. Hickson, M.A., F.R.S. \\ (Professor of Zoology in the Victoria University of Manchester.)
}

THE principal feature of interest in these collections is the presence of a single fine specimen of Corallium maderense. Only one other specimen of this species has hitherto been obtained, and no specimen of the family has hitherto been recorded from the Bay of Biscay.

The occurrence of Sympodium coralloides in the Bay is also a feature of some interest, but not very surprising, as it is in other localities usually associated with the Madreporarian corals on which it was found.

\section{ALCYONARIA.}

FAMILY ALCYONIID开.

\section{Alcyonium coralloides, Pall.}

Gorgonia coralloides, Pallas, Eleuch. Zoophyt.

Alcyonium coralloides, von Koch, Zool. Jahrb., v. 1891, p. 76.

Sympodium coralloides, de Lacaze Duthiers, Archiv. de Zool. Expér., $3^{\circ}$, viii. 1900 , p. 360.

Station VII. Lat. N. $47^{\circ} 36^{\prime}$. Long. W. $7^{\circ} 31^{\prime}$. $\dot{44}$ fathoms.

A few small specimens evidently belonging to the white variety of this species are found encrusting the dead bases of the Oculinid corals. None of the specimens are large enough to enable me to reopen the question whether the species belongs to the genus Sympodium or the genus Alcyonium. Notwithstanding the very able discussion of this question by de Lacaze Duthiers, who retains the species in the genus Sympodium, I am inclined to consider the reasons given by von Koch for transferring it to the genus Alcyonium as unanswerable. In any case, it is an extremely interesting connecting link between the Stolonifera and the Alcyonacea. In the Mediterranean Sea the 
spicules are usually purplish red to pale pink in colour, but, according to de Lacaze Duthiers, pure white varieties also occur.

The species was not recorded from the Bay of Biscay either by the Caudan or the Hirondelle expeditions.

\section{Alcyonium digitatum, Linn.}

Station I. Lat. N. $48^{\circ} 25^{\prime}$. Long. W. 60 28'. 75 fathoms.

A small white unbranched specimen of this species was obtained at this station. It is noteworthy that no specimens of the species were found in the dredgings in deeper water. The Caudan expedition obtained the species at a depth of 570-600 metres.

\section{FAMILY CORALLIIDÆ.}

Corallium maderense, Johnson.

Pleurocorallium maderense, J. Y. Johnson, Procced. Zool. Soc., London, 1899, p. 60, Plates V. and VII., figs. 1 and 4.

Station XIII. Lat. N. $48^{\circ} 7^{\prime}$. Long. W. $8^{\circ} 13^{\prime} .412$ fathoms.

The type of this species was obtained by Rev. Padre Ernesto Smith, to whom it was given by a fisherman, who told him it was brought up by a fishing-line from deep water off Camara de Lobos, a village six miles to the west of Funchal. No other specimen of the species has been described. The species was placed in the genus Pleurocorallium by Johnson, but for reasons pointed out by Kishinouye ( $J$. Imp. Fish. Bureau, xiv. 1,1904), which I can confirm by my investigations on the Coralliidæ of the Siboga expedition, to be published shortly, it is inconvenient to subdivide the known species of the Coralliidæ into generic groups, and I have therefore referred it to the genus Corallium.

The specimen is $110 \mathrm{~mm}$. in length, flabellate in growth, with the verrucæ all on one side of the colony and about $70 \mathrm{~mm}$. in width. The main axis is kidney-shaped in section, $6 \mathrm{~mm} . \times 4.5 \mathrm{~mm}$. The base of attachment is broken off and the ends of many of the branches are missing, and consequently it may have been a good deal larger when in position at the bottom of the sea. The type specimen was considerably larger than this, being $300 \mathrm{~mm}$. in length and about the same in width. The specimen resembles the type in all essential respects. The ramification is not quite so profuse, and there are not so many of the "double carafe" or "opera-glass-shaped" spicules as described by Johnson, but I can find no substantial reason for making a new species.

It is perhaps the most interesting feature of the collection of Anthozoa that has been sent to me for examination to find a specimen 
of Corallium in the Bay of Biscay. No specimens of Corallium were found by the Challenger, Lightning, Porcupine, or Caudan expeditions in their explorations of the deep-sea fauna of the west coasts of France and the British Islands, but a single specimen of Corallium johnsoni was obtained by the Irish Fisheries Department in 382 fathoms off the west coast of Ireland (Hickson, Nature, vol. 73, 1905, p. 5, and Fisheries, Ireland Sci. Invest., 1905, v. [1906]). It is established therefore that Corallium does occur on the Atlantic slope of the European shores, but it is apparently very rare, or else very local in its distribution. The axis is pure white, but very hard and somewhat translucent. The coral is not of a character to command a high price, but it is possible that if a locality could be found where it occurs in considerable quantities the thicker branches would have a market value.

A series of sections through a small branch shows that the colony is female, but the ova are not, I believe, nearly mature.

Like all the other species of the genus that have been examined, C. maderense is dimorphic. The ova are borne by the siphonozooids and not by the autozooids. In this respect the species differs from C. nobile, in which the gonads are borne by the autozooids only, and resembles C. japonicum, C. konojoi, C. elatius, and C. reginoe.

\section{FAMILY ISID E.}

Isidella elongata, Gray.

Isidella elongata, Gray, Cat. Lithophytes, 1870, p. 14.

Isis elongata, Esper (see von Koch, Fauna and Flora, Naples, Monog., xv. 1887, p. 90, plates and figures).

Station XIII. Lat. N. $48^{\circ} 7^{\prime}$. Long. W. $8^{\circ} 13^{\prime}$. 412 fathoms.

The name of this species has been subject to many changes, and it would form an interesting subject for a specialist in such matters to determine which, according to the rules of nomenclature, is the correct one. It was described as a new species by von Koch in 1878 (Morph . Jahrb. iv. 126), by the name Isis neapolitana. In 1882 he changed the name to Isidella elongata, Esper (Mitt. Zool. Stat. Neapel, bd. iii. 537). In 1887 it is described by the same author as Isis elongata, Esper, but in a "Nachtrag" is referred back again to the genus Isidella. I am in agreement with Wright and Studer (Chall. Reports, xxxi., 1889) in thinking it is doubtfully synonymous with Isis elongata of Esper, but it may be the same as Mopsea elongata of Philippi and Mopsea mediterranea of Risso. There can be no doubt, however, that it is the same as the Isidella elongata of Gray, and for that reason I have attributed the species to him. The species was obtained by the 
Caudan in $5^{\circ} 55^{\prime}$ W., $46^{\circ} 40^{\prime}$ N., $400-500$ metres. The specimen is $200 \mathrm{~mm}$. long, and gives off one slender branch $100 \mathrm{~mm}$. from the base. The axis is $2 \mathrm{~mm}$. in diameter at the base, and tapers gradually to a very slender filamentous thread at the extremity. The internodes are from 10 to $15 \mathrm{~mm}$. in length.

\section{Acanella arbuscula, Johnson.}

Mopsea arbusculum, Johnson, Proc. Zool. Soc., 1862, p. 245, Pl. XXXI. figs. 1, 1a.

Acanella arbuscula, Gray, Cat. Lith., 1870, p. 16, woodcut.

Station XIII. Lat. N. $48^{\circ} 7^{\prime}$. Long. W. 8 13'. 412 fathoms.

This is a characteristic species of the Atlantic slope. It was first described by Johnson from Madeira. It was found by the Challenger in 1525 fathoms S.W. of the Canaries. It was found in no less than four stations at depths of from 950 to 1710 metres in the Bay of Biscay by the Caudan.

Being very brittle owing to the alternating calcareous and horny joints of the axis, the specimens always reach the systematist considerably broken.

In the Huxley collection there is a main axis with nearly all the branches broken off that is $150 \mathrm{~mm}$. in length, the calcareous internodes $10 \mathrm{~mm}$. in length, and the greatest diameter of the stem $5 \mathrm{~mm}$.

The most perfect " bushy part" of a colony is $105 \mathrm{~mm}$. in height by $55 \mathrm{~mm}$. in diameter.

\section{FAMILY MURICEID曆.}

Acanthogorgia ridleyi, Wright and Studer.

A. ridleyi, Wright and Studer, Challenger Reports, vol. xxxi. 1889, p. 95, Plates XXII. and XXV.

Station VII. Lat. N. $47^{\circ} 36^{\prime}$. Long. W. $7^{\circ} 31^{\prime}$. $\dot{\overline{444}}$ fathoms.

1 specimen.

Station XIII. Lat. N. $48^{\circ} 7^{\prime}$. Long. W. $8^{\circ} 13^{\prime}$. 412 fathoms.

5 specimens.

I have had a great deal of difficulty in determining the species of the specimens of Acanthogorgia obtained by the Huxley. A great many species of this genus have been described by authors, and in most cases from the examination of a single specimen. There is no account of the range of variation within the limits of a single species. There can be little doubt, I think, that when the genus is overhauled the number of species will be materially reduced. Having compared our specimens with the species in the British Museum, I have found 
that they resemble very closely those attributed to Acanthogorgia ridleyi obtained by the Challenger off Patagonia.

This species was also discovered by the Caudan expedition at their station $6^{\circ} 21^{\prime}$ W., $45^{\circ} 47^{\prime}$ N., 1410 metres. The species obtained by the Hirondelle expeditions from the Golfe de Gascoyne are attributed by Studer to $A$. truncata and $A$. horrida, but these came from much shallower water (240 metres and 200 metres respectively). The spicules are much larger than those of the type of Acanthogorgia ridleyi, and resemble more closely the spicules of $A$. muricata, Verrill. The longest of the bent spindles are $1.2 \mathrm{~mm}$. in length. In the other three species they do not attain to a length of $1 \mathrm{~mm}$. There is another difference between our specimens and the type in that on many of the branches the zooids are very closely crowded together, especially at their extremities, instead of being separated by intervals of 3-4 mm. The observations I have made on a small piece of a branch of one of the type specimens do not quite agree with the description given by Wright and Studer, and in so far as they differ, agree more elosely with our specimens. On comparing them I have come to the conclusion that they cannot be regarded as anything but varieties of the same species.

I may add, in conclusion, that I have compared our specimens with a small dried piece of Acanthogorgia (Blepharogorgia) schrammi of Duchassaing and Michelotti, and find them to be closely related.

\section{THE ANTIPATHARIA.}

\section{FAMILY ANTIPATHID兂.}

Stichopathes spiralis, Pourtalès.

Antipathes spiralis, Pourtalès, Bull. Mus. Comp. Zool., 1880, p. 114, Pl. III.

Stichopathes pourtalesi, Brook, Challenger Reports, xxxii. 1889, p. 89.

Station VII. Lat. N. $47^{\circ} 36^{\prime}$. Long. W. $70^{\circ} 31^{\prime}$. $\dot{\overline{444}}$ fathoms.

2 specimens.

Station XIII. Lat. N. $48^{\circ} 7^{\prime}$. Long. W. $8^{\circ} 13^{\prime} .412$ fathoms. 4 specimens.

This species was obtained by the Caudan at Stations IV. and X., in 1410 and 1220 metres respectively.

Parantipathes larix, Esper.

Antipathes larix, Esper.

Parantipathes larix, Brook, Challenger Reports, vol. viii. 1889, p. 142. 
“HUXLEY" FROM NORTH SIDE OF THE BAY OF BISCAY, AUGUST, 1906. 11

Station XIII. Lat. N. $48^{\circ} 7^{\prime}$. Long. W. $8^{\circ} 13^{\prime} .412$ fathoms.

There are six specimens in the collection, varying in length from $225 \mathrm{~mm}$. to $325 \mathrm{~mm}$. The species was obtained by the Caudan in 1220 metres.

\section{FAMILY SCHIZOPATHID压.}

Schizopathes crassa, Brook.

Station XIII. Lat. N. $48^{\circ} 7^{\prime}$. Long. W. $8^{\circ} 13^{\prime} .412$ fathoms.

1 specimen.

Schizopathes crassa, Brook, Challenger Reports, xxxii. p. 147.

This species was originally found by the Challenger in 1900 fathoms off Monte Video, but it was subsequently discovered by the Caudan at Station XVI., $5^{\circ} 53^{\prime}$ W., $45^{\circ} 38^{\prime}$ N., in 1220 metres.

The specimen is broken at the base, and is about $530 \mathrm{~mm}$. in total length. The lateral branches arise sometimes in pairs, sometimes alternately, sometimes irregularly, from a strip of about one-third the width of the total circumference of the main axis, and are in two series, inclined at an angle of about $30^{\circ}$ to each other. The lateral branches in the middle region are $250 \mathrm{~mm}$. in length, those at the distal end very much shorter. At the proximal end the branches are broken.

The zooids seem to be about the same size as the type specimen, that is about $3 \mathrm{~mm}$. in a diameter transverse to the axis, but the tentacles are much more contracted than those of the Challenger specimen, and are not more than $3 \mathrm{~mm}$. in length (cf. $4-7 \mathrm{~mm}$. in the type).

The character of the spines on the axes corresponds with the description of the type. Although there is a difference in the manner in which the lateral branches arise from the main stem between the Huxley and Challenger specimens, there is no good reason, in my opinion, for regarding them as distinct species.

The species was also found in the Bay of Biscay in 1220 metres by the Caudan.

\section{THE IMADREPORARIA.}

FAMIL TURBINOLIID正.

Caryophyllia clavus, Scacchi.

Caryophyllia clavus, de Lacaze Duthiers, Archiv. de Zool. Expér., 3, v. 1897, p. 37 , and $3^{\circ}$, vii. 1899 , p. 529 .

Station I. Lat. N. $48^{\circ} 25^{\prime}$. Long. W. $6^{\circ} 28^{\prime} .75$ fathoms.

Station II. Lat. N. $48^{\circ} 24^{\prime}$. Long. W. $6^{\circ} 28^{\prime} .75$ fathoms.

Station V. Lat. N. $47^{\circ} 48^{\prime}$. Long. W. $7^{\circ} 46^{\prime}$. 109 fathoms.

Station VII. Lat. N. $47^{\circ} 36^{\prime}$. Long. W. $7^{\circ} 31^{\prime}$. $\dot{444}$ fathoms. 


\section{ALCYONARIA, ANTIPATHARIA, AND MADREPORARIA COLLECTED BY THE}

This is a common species off the coast of Ireland (Stephens), in the Bay of Biscay (Roule), and in the Mediterranean Sea.

The Mediterranean species of Caryophyllia have been carefully studied by de Lacaze Duthiers, and on the diagnoses given by the distinguished French naturalist I have no difficulty in assigning all the specimens that I have examined to the species C. clavus. It is true that a few specimens appear to approach C. "Smithii, which de Lacaze Duthiers regards as a distinct species and not a mere variety of $C$. clavus. The following measurements taken at random will express better than words the fact that the crown has the characteristic oval outline of $C$. clavus rather than the round outline of C. Smithii:-

\begin{tabular}{|c|c|c|c|c|}
\hline Height & $\mathrm{m}$. & 21 & 1 & 6 \\
\hline um diameter & $22 \mathrm{~mm}$. & 19 & & 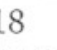 \\
\hline Minimum diameter. & $14.5 \mathrm{~mm}$. & 12 & 1 & $2 \cdot 5$ \\
\hline
\end{tabular}

There is a complete series of specimens from the maximum size, the measurement of which is given in the first column to specimens less than $1 \mathrm{~mm}$. in diameter. The collection would be of great value to any one willing to undertake a systematic study of the variations of the species.

The species was also obtained by the Caudan, and is common in deep and occasionally found in shallow water in the Mediterranean Sea (de Lacaze Duthiers).

Desmophyllum cristagalli, Milne Edwards and Haime.

Desmophyllum ingens, Moseley, Challenger Reports, vol. ii. 1881, p. 160.

Station VII. Lat. N. $47^{\circ} 36^{\prime}$. Long. W. $7^{\circ} 31^{\prime}$. $\dot{444}$ fathoms.

There are four specimens of this species in the collection. The name $D$. ingens was given to some "gigantic" specimens obtained by the Challenger in 345 fathoms in the fiords of Patagonia. I am inclined to agree with Roule that these specimens cannot be separated from the older species $D$. cristagalli.

The following measurements may be of some interest:-

$\begin{array}{lrrrrrr} & \begin{array}{c}\text { Extreme } \\ \text { length. }\end{array} & & \begin{array}{c}\text { Greatest } \\ \text { diameter of } \\ \text { the calyx. }\end{array} & \begin{array}{c}\text { Shortest } \\ \text { diameter of } \\ \text { the calyx. }\end{array} \\ \text { Largest Challenger specimen } & . & 135 & \ldots & 82 & \ldots & 50 \\ \text { Largest Huxley specimen . } & . & 100 & \ldots & 37 & \ldots & 25 \\ \text { Huxley } \text { specimens 2 and 3 } & . & 75 & \ldots & 33 & \ldots & 25 \\ \text { Huxley } \text { specimen 4 . } & . & 55 & \ldots & 22 & \ldots & 17\end{array}$




\section{OCULINID死.}

Lophohelia prolifera, Pall. Amphihelia oculata, Linn.

Amphihelia ramea, Muiller.

Station VII. Lat. N. $47^{\circ} 36^{\prime}$. Long. W. $7^{\circ} 31^{\prime}$. $\frac{\dot{44}}{44}$ fathoms. Station XIII. Lat. $48^{\circ} 7^{\prime}$ N. Long. $8^{\circ} 13^{\prime}$ W. 412 fathoms.

There can be no doubt that the corals obtained by the Huxley at these stations are the same as those obtained by the Porcupine at $59^{\circ} 56^{\prime}$ N., $6^{\circ} 27^{\prime}$ W., 363 fathoms, and some other localities in the same part of the ocean. Duncan has given a description and several excellent figures of these corals (Trans. Zool. Soc., viii. 1872, p. 330), and commented on their extreme variability. The difficulty of expressing in a diagnosis in words the difference between the species has not yet been overcome, and after carefully studying his work and that of Moseley (Challenger Reports, vol. ii. p. 178) and of de Lacaze Duthiers (Arch. Zool. Expér., 30, v. 1897), I have been unable to determine what should be, on scientific or historical grounds, the proper limits of the species. The difficulties the systematist finds in dealing with this group are: (1) the great range of variation that each species exhibits in the size of the calices, the manner of growth and ramification of the colonies, the size and even the presence of a columella, the size and the degree of exsertion of the septa, etc.; (2) the accommodation of the growth of the cœnenchym to the worm-tubes and other objects which the colonies encrust; (3) the amalgamation of the colonies of the different species.

(1) As regards the first difficulty, the calices of Lophohelia vary from 4 to $15 \mathrm{~mm}$. in diameter across the rim of the calyx, of Amphithelia oculata from 3 to $5 \mathrm{~mm}$., of Amphihelia ramea from 2 to $3 \mathrm{~mm}$., the measurements of the larger zooids only of each colony examined being taken. The presence of a columella in Amphihelia cannot be relied upon as a trustworthy character to distinguish that genus from Lophohelia. On two branches of a colony I regarded as clearly belonging to Amphihelia oculata I found that some calices had a columella, others had not, and in others the columella was rudimentary.

(2) All three species exhibit a remarkable power of forming a growth of cœnenchym over worm-tubes or other objects with which they come into contact. This power ("La puissance blastogénétique" of de Lacaze Duthiers) by determining the character or shape of the support also determines to a great extent the general character of the facies of the colony, and as all three species appear to be partial to a tubular encrusting growth round the tube of the Polychæte worm 
Eunice philocorallia, many of the colonies of the three species are very similar in their manner of growth. Many of the specimens in the collection exhibit these tubular growths of cœenenchm with the worm inside. (See F. Buchanan, Proc. R.D.S., viii. (N.S.), 1893, p. 169, and Haddon, l.c., part iv. 1895.)

(3) If we are prepared to agree with the current views that the three species are really distinct, then we must suppose that very frequently a larva of one species becomes fixed to a colony of another, and the cœenenchym of the two colonies becomes fused or amalgamated. So intimate is this amalgamation of the cœnenchyms that it is impossible to tell by surface views or the examination of the ground surface of the coral where the conenchym belonging to the one colony begins and the other ends. This difficulty has been observed by de Lacaze Duthiers. He writes (l.c., p. 149): "Les deux espèces [Lophohelia prolifera and Amphihelia oculata] très souvent sont greffées l'une sur l'autre et se ressemblent extrêmement." And in attempting to distinguish between them he writes (p. 151): "J'avais pensé que peut-être la texture intime microscopique donnerait quelques indications. Après avoir fait des coupes minces bien polies, je n'ai pas trouvé de grandes différences entre la tige de l'Amphihelia et celle du Lophohelia."

The position of the problem appears to be as follows: All the authors who have examined the species agree that they are very variable, but no one has yet made a serious attempt to determine the range of variation in any one species. Until we know whether the species really merge and overlap, or do not, it is little better than a waste of time to attempt to determine the species by the ordinary methods of the systematist. To throw some light on the problem a systematic study should be made of the range of variation in one or more large colonies of the three "supposed" species. The collection obtained by the Huxley affords sufficient and excellent material for such an investigation, and it may be suggested that such an investigation might be undertaken. 